\title{
Perilaku Pekerja Seks Komersial Dalam Penggunaan Kondom Untuk Pencegahan Transmisi HIV/AIDS Di Lokalisasi Teleju Kota Pekanbaru
}

\author{
Behaviour of Commercial Sex Workers in Condom Utilization for Prevention of \\ Transmission of HIV / AIDS at Prostitute Localization Pekanbaru
}

\section{Marlina* Suyanto **, Noorsaid Masadi***}

*Bagian Ilmu Kesehatan Masyarakat Fakultas Kedokteran Universitas Riau

**Mahasiswa Fakultas Kedokteran Universitas Riau

***Bagian Ilmu Penyakit Kulit dan Kelamin Fakultas Kedokteran Universitas Riau

\begin{abstract}
Abstrak
Prevalensi HIV AIDS di Pekanbaru meningkat dengan pesat di tahun belakangan ini, meskipun sudah dilakukan kampanye nasional mengenai pemanfaatan kondom pada kelompok risiko tinggi terutama pada pekerja seks wanita dan kliennya. Penelitian ini meneliti faktor-faktor yang mempengaruhi perilaku dari perempuan pekerja seks dalam pemanfaatan kondom dengan menggunakan pendekatan kualitatif. Data dikumpulkan dengan wawancara mendalam dan diskusi kelompok terfokus kemudian dianalisis dengan menggunakan matriks konten. Penelitian ini dilakukan di Lokalisasi Prostitusi di Pekanbaru pada Maret 2010. Hanya 16,6\% dari 30 responden menggunakan kondom secara konsisten, pada umumnya sering berubah pikiran ketika klien memberikan uang lebih banyak untuk tidak menggunakan kondom. 80\% responden tidak memahami dengan baik tentang pencegahan HIV dan pentingnya menggunakan kondom secara konsisten selama aktivitas seksual. Menariknya, pasokan kondom secara teratur diberikan oleh bos mereka. Tingkat pemanfaatan kondom rendah karena adanya penolakan klien, ketidakseimbangan gender dan tawaran uang. Kemungkinan faktor dasar adalah rendahnya pengetahuan pekerja seks tentang HIV. Intervensi yang komprehensif sangat penting untuk mengatasi hambatan perilaku tersebut.
\end{abstract}

Kata Kunci : Perilaku, Pekerja Seks, Pencegahan HIV/AIDS, Pekanbaru

\begin{abstract}
The Prevalence of HIV AIDS in Pekanbaru is growing rapidly in recent year, even though there are some national control actions by mass campaign of condom utilization among high risk group particularly in Female Sex workers and her clients. This study investigated the factors influencing of Female Sex workers behavior in the condom utilization by using qualitative approach. Data collected with in-depth interview and Focus group discussion then analyzed by content matrix. This study was held at Prostitute Localization in Pekanbaru on March 2010. Only 16.6\% of 30 respondents used condom consistently, others commonly changed her mind when client gave more money for not using condom. $80 \%$ of respondent did not understand well about HIV prevention and importance of using condom consistently during sexual activity. Interestingly, condom supply regularly provided by their boss. the condom utilization rate were low due to client resistance, imbalance gender and financial bargaining as well. Poor sex worker's knowledge about HIV perhaps the basic factor. Comprehensive interventions are crucial for addressing these behavior barriers.
\end{abstract}

Keywords: Behaviour, sex workers, HIV / AIDS Prevention, Pekanbaru

${ }^{1}$ Alamat korespondensi: Suyanto, Fakultas Kedokteran Universitas Riau, JI Diponegoro, Pekanbaru. HP. 081275200615 


\section{Pendahuluan}

Penyakit Acquired Immuno Deficiency Syndrome (AIDS) menarik perhatian komunitas kesehatan pada saat pertama kali ditemukan tahun 1981 yang prevalensinya saat ini meningkat sangat pesat ini. ${ }^{1}$ AIDS dapat diartikan seabagai kumpulan gejala atau penyakit yang disebabkan Human Imunodeficiency Virus (HIV). AIDS merupakan tahap akhir dari infeksi HIV. (Djoerban Z, Djauzi S. 2006. Siregar FA 2009)

Kasus AIDS pertama didunia dilaporkan pada tahun 1981. Menurut United Nations Joint Programme on HIV/AIDS (UNAIDS) pada tahun 1996 sekitar sekitar 400 ribu anakanak dibawah umur 15 tahun telah terinfeksi HIV/AIDS. Menurut World Health Organizationi (WHO) dan UNAIDS, pada tahun 2002 secara epidemiologik, lebih dari 3 juta orang hidup dengan HIV dan 5 juta dengan AIDS dan Desember tahun 2004, jumlah Orang hidup dengan HIV/AIDS (ODHA) di dunia mencapai estimasi 35,944,3 juta orang. Saat ini tidak ada negara yang terbebas dari HIV/AIDS( Hasyim R, Firman NS2009).

India merupakan Negara dengan angka kasus HIV/AIDS tertinggi dikawasan asia dengan urutan kejadian yang diperkirakan hampir 4 juta orang dewasa,kemudian diikuti oleh Thailand, Kamboja dan Myanmar. (Hasyim R, Firman NS2009).

Indonesia merupakan salah satu negara Asia yang mengalami pandemi HIV/AIDS dengan prevalensi yang meningkat tajam dan belum menunjukan penurunan meskipun upaya penanggulangan HIV/AIDS telah dilaksanakan oleh masyarakat, Lembaga Swadaya Masyarakat (LSM) dan swasta. ${ }^{1}$ Kasus AIDS pertama di Indonesia dilaporkan secara resmi oleh Departemen Kesehatan tahun 1987 yaitu pada seorang warga Negara Belanda di Bali, dari tahun ketahun menunjukan peningkatan.( Djoerban Z, Djauzi S. 2006).

Virus HIV ditemukan dalam cairan tubuh terutama pada darah, cairan sperma, cairan vagina, air susu ibu. Penularan HIV/AIDS dapat melalui 3(tiga cara) yaitu: (1) hubungan seksual secara genital, anogenital, maupun orogenital dengan seorang pengidap HIV/AIDS. (2) Kontak langsung dengan darah atau produk darah/jarum suntik. (3) Secara vertikal yaitu yaitu dari ibu hamil pengidap HIV kepada bayinya, baik selama hamil, saat melahirkan atau saat menyusui. (Notoatmodjo S. 2007. Nasrodin.2007)

Perkembangan kasus HIV di Indonesia berkembang dari sejumlah kasus kecil dan memasuki tahap epidemis dengan beberapa sub-populasi berisiko tinggi yang memiliki angka kasus diatas 5 persen. Salah satu hal yang ada di indonesia adalah tingginya tingkat kemunculan kasus HIV/AIDS. (Hugo G. 2001)

Berdasarkan data Ditjen PPM \& PL Depkes (2008) jumlah pengidap infeksi HIV AIDS yang dilaporkan 1 Januari sampai dengan 31 Desember 2008 adalah 5458 kasus, diantaranya 489 merupakan pengidap infeksi HIV dan AIDS ada 4969 kasus. Secara kumulatif pengidap infeksi HIV dan kasus AIDS 1 Oktober tahun 1987 sampai dengan 31 Desember tahun 2008 terdiri dari 22664 kasus yang diantaranya 6554 pengidap HIV dan 16110 menderita AIDS dan 3362 mengalami kematian. (Ditjen PPM, PL Depkes RI, 2008).

Berdasarkan jenis kelamin kasus AIDS pada laki-laki terdapat $74,8 \%$ dan perempuan $24,6 \%$. Faktor resikonya pada heteroseksual 47,9\%, Injection Drug User (IDU) 42,2\%, homoseksual $0,4 \%$, tranmisi perinatal $0,2 \%$ yang $80 \%$ nya merupakan golongan umur 20 sampai 39 tahun. Jumlah kumulatif kasus AIDS di Jawa Barat 2888, DKI Jakarta 2781, Jawa Timur 2591, Papua 2382, Bali 1177, Kalimantan Barat 730, Jawa Tengah 530, Sumatera Utara 487 dan Riau 364 Kasus. ${ }^{8}$

Berdasarkan data dari Dinkes Provinsi Riau (2009) angka tertinggi kasus AIDS terbesar di Kota Pekanbaru dan Dumai. Dari tahun1998 sampai Maret 2009 ditemukan 349 kasus. Kota Pekanbaru terdapat 234 kasus dan yang menjadi faktor resiko tertinggi adalah 
heteroseksual yang diantaranya bekerja sebagai wiraswasta 69 kasus, swasta 52 kasus, karyawan 12 kasus, buruh dan pekerja seks komersial 4 kasus. (KPA Kota Pekanbaru, 2009).

Salah satu kebijakan penanggulangan HIV/AIDS adalah upaya pencegahan yang efektif termasuk penggunaan kondom $100 \%$ diantara PSK dengan pelanggannya, pasangan ODHA serta pemanfaatan fungsi ganda (dual protection) kondom dalam keluarga. ${ }^{10}$ Akan tetapi, Roselly Evianty Silalahi (2008) melakukan penelitian di Lokalisasi Telaju Kota Pekanbaru dinyatakan bahwa hanya $17,7 \%$ dari 130 PSK yang memakai kondom saat berhubungan dengan pelanggan. ${ }^{11}$

Menghapuskan sama sekali kegiatan para PSK, misalnya rencana penutupan lokalisasi atau operasi penertiban, tampaknya tidak mungkin. Hal ini justru akan menimbulkan dampak lain dan tidak menyelesaikan masalah. Hal yang paling mungkin dilakukan adalah mencegah agar dampak negatif yang ditimbulkan tidak meluas ke masyarakat dengan cara pencegahan penularan HIV dengan upaya menjauhi hubungan seks berganti pasangan tanpa kondom, bersikap setia, gunakan kondom dan hindari pemakaian narkotika suntik. Keberhasilan dari pencegahan penularan HIV/AIDS, sangat tergantung dari pengetahuan, sikap dan tindakan atau praktek yang dimilki dalam pencegahan penyakit HIV/AIDS. ${ }^{12}$

Berdasarkan uraian diatas penulis tertarik untuk mengetahui perilaku pekerja seks komersial (PSK) dalam penggunaan kondom sebagai media pencegahan HIV/AIDS di lokalisasi Teleju Kota pekanbaru.

\section{Metode}

Jenis penelitian ini adalah deskriftif pendekatan kualitatif yang bertujuan untuk mendapatkan pengetahuan, sikap, dan praktek PSK terhadap upaya pencegahan HIV/AIDS dilokalisasi Teleju Kota Pekanbaru. Penelitian dilakukan Lokalisasi Teleju kota Pekanbaru. Penelitian dilakukan pada bulan Januari 2010 sampai Maret 2010. Veriabel penelitian ini adalah Manusia (PSK), Meterial, Pelanggan (pelanggan dalam suasana tidak kondusif),
Lingkungan, Metode, Perilaku pemakaian kondom pada PSK. Teknik dan instrumen pengumpulan data yang digunakan pada penelitian ini adalah wawancara mendalam dan Focus Group Discastion (FGD). Analisis kualitatif dengan menggunakan analisa isi (content analysis) untuk mendapatkan informasi mendalam tentang perilaku PSK dalam memakai kondom sebagai media pencegahan HIV/AIDS di Lokalisasi Teleju, dengan cara mencatat, dibuat matrik dan analisis secara manual.

\section{Hasil}

\section{Pengetahuan Responden}

Informasi yang didapat dari penelitian tantang pengetahuan informan tentang HIV/AIDS meliputi hal berikut :

\section{Mendengar informasi HIV/AIDS dan sumber informasi}

Hasil penelitian di dapat informasi bahwa masing-masing infornan sudah pernah mendengar atau mendapatkan informasi mengenai HIV/AIDS. Sumber informasi pada umumnya dari yayasan utama seperti pada pernyataan berikut:

"Aku pernah dari yayasan"

(FGD informan 1).

"Aku sering dengar kog, aku sering ikut

penyuluhan di sanggar dari yayasan"

(wawancara mendalam informan 6).

Berdasarkan hasil wawancara dan FGD pada umumnya informan dari yayasan utama.

\section{Pengertian HIV/AIDS}

Dari hasil penelitian didapat informasi bahwa masih ada pendapat yang keliru tentang pengertian HIV/AIDS, seperti berikut

"Katanya sih HIV itu penyebab penyakit AIDS, AIDS mah penyakit yang menular melalui alat kelamin ya kak"

(wawancara mendalam informan 3)

"HIV penyebab AIDS, AIDS itu penyakit menular karna sering ngewek dengan banyak orang"

(FGD informan 7)

"Penyakit Kutukan" 
(FGD informan 3)

"Kebanyak ngewek"

(wawancara mendalam informan 15)

Berdasarkan hasil wawancara dan FGD informan sudah ada yang benar tapi masih ada yang keliru.

\section{Cara penularan HIV/AIDS}

Hasil penelitian didapat bahwa informan masih ada yang belum menegetahui bagaimana cara penularan HIV/AIDS dan pendapat informan masih keliru dan kurang tepat.

"Malalui gigitan nyamuk, karna kebanyakan ngewek, nggak tau mbak" (wawancara mendalam informan 2)

"Melalui gigitan nyamuk"

(FGD informan 3).

Berdasarkan hasil wawancara dan FGD masih ada yang keliru menganggap penularan HIV/AIDS melalui gigitan nyamuk.

Dari hasil penelitian juga didapat pendapat informan yang sudah tepat tentang penularan HIV/AIDS, seperti berikut:

"Melalui jarum suntik, bertukar jarum suntik pada pemakai narkoba, melalui ngewek dan nggak pakai kondom"

(FGD informan 1)

Berdasarkan hasil FGD didapat pendapat informan tentang cara penularan HIV/AIDS melalui jarum suntik pada pengguna narkoba,melalui hubungan seksual tanpa pengguna kondom dan melalui oral seks.

\section{Kegunaan kondom}

Dari hasil penelitian didapatkan kegunaan kondom agar tidak tertular HIV namun juga masih banyak yang keliru.

"Biar memek kita nggak nular penyakit tamu. Dari sanggar"

(wawancara mendalam informan 5)

"Biar nggak nular penyakit HIV, ada pas nonton tv"

(wawancara mendalam informan 6)

“Yang jelas kata mamiku, klo kita pake

kondom lebih terjamin dan tdk menularkan penyakit kelamin dan HIV."
(FGD informan 8)

Berdasarkan hasil wawancara di atas di dapat bahwa cara pencegahan penularan HIV pakai kondom.

\section{Sikap Responden}

\section{Pendapat tentang penggunaan kondom}

Dari hasil penelitian didapat tentang sikap informan terhadap penggunaan kondom setuju, seperti pada pernyataan informan berikut :

"Ya pake.. ya langsung dipake.. ya pandaipandai kita merayu, tunggal bilang aja disini kt dianjurin pake kondom bang," (wawancara mendalam informan 1)

"setuju sekali, itukan tergantung tamunya juga, kalau kita kan biar aman"

(FGD informan 6)

"Sangat setuju sekali, dan kita harus selalu menyuruh tamu"

(FGD informan 13)

Berdasarkan hasil wawancara dan FGD informan setuju penggunaan kondom untuk mencegah penularan HIV/AIDS tetapi masih banyak tamu yang menolak untuk memakainya.

\section{Pemeriksaan kesehatan secara rutin}

Hasil penelitian diperoleh informasi bahwa sikap informan tentang pendapat pemeriksaan kesehatan rutin setuju , seperti pada pernyataan berikut :

"Sangat perlu itu kak dilakukan dan aku pun mau memeriksa kedokter supaya kita tetap sehat, tapi disini tidak ada petugasnya."

(wawancara mendalam informan 4)

"Sangat perlu sekai dilakukan, tapi didekat sini harus ada klinik juga"

(FGD informan 5)

"Setuju"

(FGD informan 13).

\section{Konseling HIV/AIDS dan pemeriksaan darah}

Sikap informan tentang konseling HIV/AIDS dan pemeriksaan darah : 
"Aku setuju kak, dan aku juga mau kalau periksa darah, tapi aku kadang takut juga' nantik kalau diperiksa tau kena HIV, ihh ngeri"

(wawancara mendalam informan 3)

"Aku sangat setuju, supaya kita bisa langsung konsultasi"

(FGD informan 2)

hasil wawancara dan FGD informan setuju dilakukan konseling dan pemeriksaan darah.

\section{Khawatir tertular HIV/AIDS}

Pada umumnya informan takut tertular HIV/AIDS, Karena banyak tamu yang tidak mau memakai kondom saat berhubungan.

"Aku takut mbak, karena tamu kan banyak yang nggak mau pakai kondom pas lagi ngewek"

(wawancara mendalam informan 5)

"Sangat khawatir, karna tamu kan banyak nggak pakai kondom"

(FGD informan 4)

"Takut sekali"

(FGD informan 9)

Berdasarkan hasil wawancara dan FGD didapatkan bahwa informan khawatir tertular HIV/AIDS karena masih banyak tamu yang menolak untuk memakai kondom saat berhubungan.

\section{Kebersihan alat kelamin}

Hasil penelitian diperoleh informasi bahwa pada umumnya sikap terhadap upaya menjaga kebersihan alat kelamin sudah baik namun masih ada yang keliru.

"Perlu sekali, selain supaya bersih kita juga terhindar dari penyakit, pakai saja sabun sirih"

(wawancara mendalam informan 10)

"Sangat perlu dilakukan, setiap habis gitu sama tamu harus lah"

(FGD informan 2)

"Sangat perlu dilakukan, setiap habis gitu sama tamu harus lah, bersihkan pakai odol katanya bagus."

(FGD informan 10)
Berdasarkan hasil wawancara dan FGD semua setuju dengan upaya menjaga kebersihan alat kelamin.

\section{Pendapat tentang pengidap HIV/AIDS}

Hasil penelitian didapat data bahwa pada umumnya menyatakan bahwa pada umumnya informan menyatakan bahwa pengidap HIV/AIDS harus dijauhi, supaya jangan tertular, ada juga yang mengatakan boleh tinggal serumah asal jangan dekat, dan ada juga telah benar.

"Harus dijauhi"

(wawancara mendalam informan 6)

"Jangan didekatilah, dan jangan bersentuhan langsung sama kita, dan kita harus hati-hati"

(wawancara mendalam informan 11)

"Jangan didekati aja"

(FGD informan 3)

"Kenapa harus dijahui, mereka bisa kok tinggal bersama kita"

(FGD informan 4)

Berdasarkan hasil wawancara dan FGD, informan mengatakan menjauhi karena takut tertular tetapi ada juga yang benar tidak harus menjauhi dan msaih bisa tinggal bersama.

\section{Tindakan Responden}

\section{Tindakan untuk pencegahan penularan HIV/AIDS}

Dari hasil penelitian didapatkan gambaran bahwa tindakan informan untuk mencegah HIV/AIDS informan sudah mau menggunakan kondom dengan cara menawarkan ke tamu, seperti pernyataan berikut:

"Ya pakai kondom,, ya kadang-kadang, kadang tamunya gk mau... tapi kita kan ngejar setoran."

(wawancara mendalam informan 1)

"Pakai kondom kak, tapi kan tamunya yang pake, nggak setiap kali ngewek dipake, ada juga yang udah mau pake kondom tapi pas sedang eh malah dibuka." (FGD informan 3) 
"Pakai kondom, yaitu dengan merayu tamu supaya pakai kondom, tapi kalau tamunya nggak mau pake ya teta ngewek juga, kita mau cari duit gimana lagi"

(FGD informan 4)

Berdasarkan hasil wawancara dan FGD informan mau dan sudah mewarkan kondom ke tamu tetapi mereka tergantung tamu juga.

\section{Menawarkan kondom}

Hasil penelitian diperoleh informasi bahwa pada umumnya informan menyatakan selalu menawarkan kondom kepada tamu menggunakan kondom.

"Aku tetap tawarin pakai kondom, itupun terserah ama tamu kalau mau syukur, kalo nggak gimana lagi tetap ngewek" (wawancara mendalam informan 6)

"Saya tetap tawarin pakai kondom ke tamu yang datang, tapi kalo nggak mau ya udah layanin aja mau gimana lagi udah kerja" (wawancara mendalam informan 13)

"Tetap tawarin tamu, tapi nggak dipaksa juga"

(FGD informan 7)

Berdasarkan hasil wawancara dan FGD sebagian besar informan sudah mau menawarkan kondom ke tamu, tetapi untuk menggunakannya tergantung tamu.

\section{Upaya jika tamu menolak}

Berdasarkan hasil penelitian upaya yang dilakukan jika tamu menolak menggunakan kondom, sebagaimana dinyatakan berikut ini:

"Ya dirayu dulu, klo msh gak mau ya nggak apa-apa, dari pada kluar gk dapat duit, kan ngejar setoran."

(wawancara mendalam informan 1)

"Tetap layani, tapi liat dulu kelamin nya bersih ato nggak. Kalo ada yg aneh aku nggak mau."

(FGD informan 3)

"Tetap main, karna ngejar setoran kak." (FGD informan 4)

Berdasarkan hasil wawancara dan FGD didapatkan upaya yang dilakukan jika tamu menolak menggunakan kondom tetap melayani dengan alas an mengejar setoran.

\section{Mendapatkan kondom dan stok kondom}

Dari hasil penelitian didapatkan informa pada umumnya mereka menyatakan mudah mendapatkan kondom karena dari yayasan utama selalu member kondom, kadang beli diwarung, dan pada umumnya tetap mempunyai stok kondom dikamar masingmasing. Seperti terungkap pada pernyataan berikut:

"Ya ada dikamar.. ya dibeliin mami." (wawancara mendalam informan 1)

"Ada. Kondom yang di bagikan orang yayasan."

(wawancara mendalam informan 5)

"Kami biasa dibagikan sama kakak dari kaka yayasan secara gratis, merekakan sering membagikan dan nanya masih ada stok, kondom tetap ada sebagai persiapan" (FGD informan 2)

"Stok kondom selalu ada kamar anakanak.... Nggak pernah sampai kosong” (Key Informan yaitu mami)

Berdasarkan hasil wawancara dan FGD sebagian besar informan mudah mendapatkan kondom, dan persediaan kondom tetap tersedia.

\section{Tindakan menjaga kebersihan alat kelamin}

Hasil penelitian menggambarkan bahwa tindakan informan untuk menjaga kebersihan alat kelamin masih ada yang keliru, seperti terlihat pada pernyataan berikut:

"Selesai ngewek langung saya kasih odol dan saya cuci pake sabun, biar bersih." (wawancara mendalam informan 3)

"Pernah bahkan sampai lecet, bersihin pakai odol supaya dingin"

(FGD informan 14)

Berdasarkan hasil wawancara dan FGD masih ada sebagian informan membersihkan alat kelamin setelah berhubngan dengan menggunakan odol.

Namun dari hasil penelitian juga didapat informasi bahwa informan dalam membersihkan alat kelamin sudah baik, seperti terungkap pada pernyataan berikut: 
"Nggak pernah keputihan, karena bis gituan pasti dicuci ma sabun sirih."

"Cuci ma sabun sirih"

(FGD informan 10)

Berdasarkan hasil wawancara dan FGD bahwa sebagian besar informan sudah melakukan tindakan membersihakan alat kelamin dengan menngunakan sabun sirih.

\section{Upaya pencarian fasilitas kesehatan}

Hasil penelitian didapat gambaran bahwa informan jika punya keluhan kesehatan masalah sekitar alat kelamin mereka pergi ke dokter dan bidan. Seperti terungkap pada pernyataan berikut:

"Nggak pernah keputihan, karena bis gituan pasti dicuci ma sabun sirih." (wawancara mendalam informan 2)

"Bilang ke mami, ntar dibawa ke praktek bidan, bis disini nggak ada klinik"

(FGD informan 10)

Berdasarkan hasil wawancara dan FGD mereka pergi ke dokter atau kebidan.

\section{Penanggungan biaya fasilitas kondom}

Penanggungan biaya kondom gratis dibagikan kepada informan oleh Yayasan Utama, dan sebagian ada dibebankan ke tamu dan mami.

"Gratis dari yayasan"

(wawancara mendalam informan 3)

"Kalo dari yayasan gratis, kalo sutra kan beli jadi minta duit ma tamu."

(FGD informan 3)

"disediakan mami "

(FGD informan 11).

Berdasarkan wawancara dan FGD, biaya kondom dari LSM Yayasan Utama yang diberikan kepada informan secara gratis, dan ada juga yang dibebankan ketamu serta mami.

\section{Pembahasan}

Pengetahuan informan tentang pengertian HIV/AIDS, masih ada yang masih keliru dan pendapat mereka kurang tepat. Namun ada juga sebagian kecil sudah menjawab dengan baik walaupun pendapat mereka belum sempurna tentang pengertian HIV/AIDS. Selanjutnya ada juga sebagian kecil informan yang tidak mengetahui sama sekali tentang HIV/AIDS. Adanya pendapat informan yang masih keliru mungkin disebabkan kurangnya daya tangkap informan terhadap informasi HIV/AIDS walaupun sudah sering mendapatkan informasi tersebut, juga karena diiringi dengan tingkat pendidikan yang rendah. Menurut konsep Green(1980) dalam Notoatmodjo, bahwa tingkat pendidikan akan mempengaruhi pengetahuan seseorang. Makin tinggi tingkat pendidikan seseorang maka semakin tinggi pengetahuan seseorang terhadap suatu objek.

Pengetahuan mengenai cara penularan HIV/AIDS informan sudah banyak yang mengetahui melalui hubungan seksual, melalui jarum suntik bagi pengguna narkoba. Namun ada sebagian kecil informan yang masih keliru tentang cara penulran HIV/AIDS, ada yang mengatakan melalui gigitan nyamuk. Menurut Nasrodin bahwa cara penularan HIV/AIDS adalah dengan melalukan hubungan seksual yang tidak aman dengan orang terinfeksi HIV, dengan menggunakan jarum suntik yang tidak steril, tranfusi darah yang terinfeksi HIV,melalui ibu hamil yang terinfeksi HIV menularkan ke bayi sewaktu hamil, melahirkan dan menyusui (Nasrodin, 2007) Dari uraian tersebut dapat disimpulkan bahwa informan yang sudah banyak mengetahui walaupun jawabannya belum lengkap dan pemahamannya masih kurang. Dalam hal ini mungkin disebabkan karena masih kurangnya daya tangkap informan terhadap informasi yang telah diberikan.

Pengetahuan informan tentang cara pencegahan infeksi HIV/AIDS pada umumnya sudah baik dan sudah tepat bagi informan yang berprofesi sebagai PSK. Menurut Depkes RI cara mencegah HIV/AIDS dengan upaya menjauhi hubungan seks berganti pasangan tanpa kondom, bersikap setia, gunakan kondom, dan hindari nerkoba suntik.

Menurut Notoatmodjo mengungkapkan pengetahuan atau kognitif merupakan domain 
yang sangat penting terbentuknya tindakan seseorang (over behavior), sehingga perlu kita perhatikan pengetahuan PSK tentang HIV/AIDS, sehingga diharapkan dengan pengetahuan yang baik maka PSK dapat berperilaku baik terhadap upaya pencegahan HIV/AIDS.

Menurut purwanto sikap adalah pandangan atau perasaan yang disertai kecenderungan untuk bertindak sesuai dengan sikap terhadap objek. Jadi sikap senantiasa terarah pada suatu hal, suatu objek, tidak ada sikap yang tanpa objek. Sifat dapat bersifat positif dan dan dapat pula bersikap negatif, dalam sikap positif kecenderungan tindakan adalah mendekati, menyenangi, mengharapkan objek tertentu, sedangkan dalam sikap negatif terdapat kecenderungan untuk menjauhi, menghindari, membenci tidak menyukai objek tertentu.

Dalam penelitian ini ditemukan sikap yang positif terhadap penggunaan kondom, konseling HIV/AIDS, pemeriksaan kesehatan secara rutin, kebersihan alat kelamin, dalam hal ini sesuai dengan pendapat Green (1980) dalam Notoatmodjo sikap termasuk dalam faktor-faktor predisposisi, faktor-faktor ini terutama yang positif mempermudah perilaku, maka disebut faktor pemudah.

Dari penelitian ini terungkap bahwa sikap yang positif belum menjamin perilaku informan menjadi positif pula, hal ini disebabkan oleh pengetahuan informan yang kurang. Menurut Purwanto pengetahuan saja belum menjadi penggerak, seperti halnya pada sikap, pengetahuan mengenai suatu objek baru menjadi sikap apabila pengetahuan itu disertai kesiapan untuk bertindak sesuai pengetahuan terhadap objek tersebut. Sedangkan penentu sikap menurut Allport (1954) yang dikutip dalam Notoatmodjo ${ }^{3}$ bahwa pengetahuan, pikiran, keyakinan dan emosi memegang peranan penting.

Tindakan informan terhadap upaya penggunaan kondom pada umumnya masih sangat kurang. Pada umumnya informan mengatakan penggunaan kondom tergantung dari tamu, kalau tidak bersedia maka mereka akan mengikuti saja, informan tidak memiliki aturan tertentu yang mengharuskan tamu harus menggunakan kondom baru dilayani. Masih kurangnya tindakan PSK dalam upaya penggunaan kondom mungkin disebabkan karena tidak adanya aturan dari PSK dalam menggunakan kondom setiap tamu yang dilayani, tidak adanya pengawasan dan motivasi tinggi dari germo kepada PSK dalam menggunakan kondom bagi tamu mereka.

Tindakan dalam menawarkan kondom ke tamu sudah cukup baik, walaupun masih ada sebagian kecil informan tidak melakukannya. Namun demikian walaupun sudah menawarkan tetapi tidak semua tamu mau menggunakan kondom.

Tindakan kebersihan alat kelamin setelah berhubungan juga bervariasi pada umumnya informan menggunakan pembersih sabun sirih, namun ada sebagian informan dalam tindakan menjaga kebersihan alat kelamin masih ada yang keliru dengan menggunakan odol untuk membersihkan alat kelaminnya setelah berhubungan seksual. Jika dilihat dari kesehatan penggunaan odol tidak baik dilakukan, karena bisa membuat alat kelamin menjadi teriritasi. Adanya tindakan yang masih keliru karena informan masih percaya dengan menggunakan dari teman mereka hal tersebut yaitu menggunakan odol disertai tingkat pengetahuan yang rendah tentang upaya pencegahan infeksi HIV/AIDS.

Untuk tindakan terhadap upaya informan untuk mendapatkan pertolongan jika memiliki keluhan kesehatan seperti keluhan disekitar alat kelamin, sudah cukup baik. Informan sudah mau berobat ke dokter, dan petugas kesehatan lainnya mendapatkan pengobatan, karena informan sangat perlu untuk menjaga tubuh tetap sehat karena mereka harus bekerja.

Untuk tindakan dalam upaya konseling HIV/AIDS dan melakukan tes darah mereka banyak mengatakan belum pernah terutama untuk melakukan tes darah, jika upaya konseling informan dapat melakukan dengan menemui kakak Yayasan Utama, Jika mereka ada permasalahan dan ingin mengetahui banyak tentang HIV/AIDS.

Pada hakikatnya memang sulit untuk langsung merubah perilaku kea rah perilaku baru, mungkin harus membutuhkan waktu 
lama dan harus mempunyai suatu peraturan yang cukup ketat. Sesuai apa yang dikatakan oleh Notoatmodjo ${ }^{3}$ perubahan atau adopsi perilaku baru adalah suatu proses yang komplek dan memerlukan waktu yang relative lama. Menurut Green (1980) dalam Notoatmodjo $^{3}$ bahwa peraturan atau perundang-undangan merupakan salah satu faktor penguat dalam mempemgaruhi perilaku.

Tindakan atau praktek kesehatan menurut Notoatmodjo $^{3}$ setelah seseorang mengetahui stimulus atau objek kesehatan kemudian mengadakan penilaian atau pendapat terhadap apa yang diketahui, proses selanjutnya diharapkan ia akan melaksanakan atau mempraktekkan apa yang diketahi atau disikapinya (dinilai positif).

Dari penelitian ini terungkap bahwa apabila pengetahuan masih kurang walaupun sikap positif sikap positif terhadap kesehatan maka prakteknya atau perilaku terhadap kesehatan akan kurang positif pula sesuai menurut Green (1980) dalam Notoatmodjo ${ }^{3}$ disimpulkan bahwa perilaku seseorang atau masyarakat tentang kesehatan ditentukan oleh pengetahuan, sikap, kepercayaan, tradisi dan sebagainya dari orang atau masyarakat yang bersangkutan.

Ternyata dari analisis diatas antara praktek atau tindakan informan dengan pengetahuan, sikap informan terhadap upaya pencegahan HIV/AIDS ada hubungan yang selaras.

\section{Kesimpulan}

Pengetahuan informan tentang HIV/AIDS pada umumnya masih rendah dan masih banyak pendapat informan yang masih keliru tentang HIV/AIDS. Banyaknya pendapat yang keliru dari informan mungkin disebabkan rendahnya daya tangkap informan disertai rendahnya tingkat pendidikan informan.

Pada umumnya sikap informan terhadap upaya pencegahan HIV/AIDS sudah cukup baik, dengan adanya ketersediaan kondom di kamar masing-masing PSK serta dukungan dari para mucikari untuk memakai kondom selama berhubungan seksual dengan pelanggan.
Tindakan informan terhadap upaya pencegahan HIV/AIDS kurang baik dalam menggunakan kondom karena adanya tekanan tamu yang tidak mau menggunakan kondom. karena bagi PSK tindakan terbaik dalam pencegahan HIV/AIDS adalah menggunakan kondom selama berhubungan seksual dengan pelanggan.

\section{Ucapan Terima Kasih}

Penulis mengucapakan terima kasih yang sebesar-besarnya kepada masyarakat Teleju atas informasi dan kemudahan yang diberikan kepada penulis selama melaksanakan penelitian ini.

\section{Daftar Pustaka}

Budiarti R. Perilaku Seks Waria dalam Upaya Pencegahan HIV/AIDS di Kota Pontianak Kalimantan Barat tahun 2007. Balai Penerbit FKM Universitas Diponegoro. [diakses 23 Mei 2009]: http://www.fkm.undip.ac.id.

Buldelines. Sexually transmitted deseases treatment. [diakses 5 Juli 2009]: http://www.medscape.com.

Burn A. Pemberdayaan Wanita dalam Bidang kesehatan. Yogyakarta: Penerbit Yayasan Essenti Medica; 2000.

Depkes RI. Modul pelatihan Konseling dan Tes Sukarela HIV (Voluntary Counseling ang Testing $=$ VCT) untuk Konselor Profesional. Jakarta: Direktorat Jenderal Pelayanan Medik dan Direktorat Jenderal P2M dan Pelayanan Lingkungan; 2004.

Depsos RI. Pola Pengembangan

Kesejahteraan Sosial. Jakarta; 2003.

Ditjen PPM, PL Depkes RI. Statistik Kasus HIV/AIDS di Indonesia dialpor s/d Desember 2008. Jakarta [diakses 18 April 2009]: http://spritia.or.id.

Diwarman. Cegah penularan HIV/AIDS dengan transmisi seks terkendali. Jakarta. [diakses 28 September 2009]: http://diwarman64.blogspot.com. 
Djoerban Z, Djauzi S. HIV/AIDS di Indonesia. Dalam: Sudoyo AW, Setioyadi B, Alwi I, Simadibrata KM, Setiadi S, editor. Buku Ajar Ilmu Penyakit Dalam. Jakarta. Balai Penerbit FKUI; 2006: 1803-12.

Duarsa WN. Infeksi HIV \& AIDS. dalam: Nalil SF, Indriatmi W, Zubier F, Judanarso J,editor. Buku Infeksi Menular Seksual. Jakarta: Balai Penerbit FKUI; 2005: 132-43.

General Info. Penggunaan kondom mencegah infeksi HIV dan PMS. UNAIR [diakses 28 September 2009] http://www.mailarchive.com/unair@itb.ac.id/msg01344.htm.

Hasyim R, Firman NS. AIDS. Jakarta. [diakses 23 Mei 2009]. dari: http://sepsis.wordpress.com/aids/.

Hudono ST, Winokjosastro H. Psikosomatik dan Seksologi. dalam: Saifudin AB, Rachimhadhi T, editor. Buku lmu Kandungan. Jakarta: Bina Pustaka; 2005: 576-615.

Hugo G. Mobilitas Penduduk dan HIV/AIDS di Indonesia. Australia: Adelaide University; 2001: 12-30, 46-89.

Kartono, Kartini. Patologi Sosial. Jakarta: Raja Grafindo; 2001.

KPA Kota Pekanbaru. Tabel Kasus AIDS per Kabupaten/ Kota Provinsi Riau sampai dengan bulan Januari 2009. Pekanbaru: Tidak di Publikasikan; 2009.

Lan VM. Virus imunodefisiensi manusia (HIV) dan sindrom imunodefisiensi dan sindrom imunodefisiensi didapat (AIDS). Edisi bahasa Indonesia Huriati hartanto [et.al]-ed, editor. Konsep Klinis Proses Penyakit. Jakarta: EGC; 2009: 38-44.

Manajement Guildelines. Sexually transmitted infections. Publihed by DS C clinic. National skin centre; 2007.

Manalu HSP, Kasnodiharjo. Pengetahuan Pekerja Seks Komersial tentang Penyakit
Menular Seksual serta sikap dan perilaku terhadap upaya pencegahannya diwilayah Jakarta dan Surabaya. Jakarta: Majalah Kedokteran Indonsesia Vol 56 nomor 9; 2006.

Mentri Pemberdayaan Perempuan. Pemberdayaan perempuan dalam pencegahan penyebaran HIV-AIDS. Jakarta: Balai Penerbit Kementrian Negara pemberdayaan perempuan RI; 2008.

Murtiastutik D. Buku ajar Infeksi Menular Seksual. Barkbah J, Lumintang H, Martudihardjo S. editor. Surabaya: Airlangga university Press; 2008.

Nasrodin. HIV \& AIDS Pendekatan Bilologi Molekuler,Klinis dan Sosial. Editor: Barakbah J, Soewandojo E, Suharto, Hadi U, Astuti WD. Surabaya: Airlangga university press; 2007: 1-44.

Notoatmodjo S. Kesehatan Masyarakat Ilmu dan Seni. Jakarta: Rineka Cipta; 2007: 31025.

Purwanto,Heri. Pengantar Perilaku Manusia untuk Keperawatan. Jakarta: EGC; 2008.

Setiawan A. Hubungan pendidikan Seks sejak dini dengan perilaku seksual pada remaja di SMA Tunas Harapan Bandar Lampung tahun 2007. [diakses 29 September 2009]: http://one.indoskripsi.com/judul-skripsi/ilmukeperawatan/hubungan-pendidikan-sekssejak-dini-dengan-perilaku-seksual-padaremaja-di-sma-tunas-harapan-b.

Silalahi ER. Pengaruh Faktor Predisposisi, Pendukung Dan Penguat Terhadap Tindakan Pekerja Seks Komersil (PSK) Dalam Menggunakan Kondom Untuk Pencegahan HIV/AIDS Di Lokalisasi Teleju Kota Pekan Baru Tahun 2008. Balai Penerbit Universitas Sumatra Utara. [diakses 23 Mei 2009]; http://library.usu.ac.id/index.php/component/j ournals/index.php?option=com_journal_revie w\&id=10405\&task=view.

Siregar FA. Pengenalan dan Pencegahan AIDS. Balai Penerbit FKM Universitas 
Sumatra Utara. [diakses 23 Mei Suryoputro A, Ford NJ, Shaluhiyah Z. Faktor2009]:http://library.usu.ac.id. faktor yang Mempengaruhi Perilaku Seksual

Sugiri. Detail rubric. Jakarta. [diakses 27 September 2009] http://www.bkkbn.go.id/webs/detailrubrik.ph $\mathrm{p}$ ? MyiD=449. Remaja di Jawa Tengah: Implikasinya terhadap kebijakan dan layanan Kesehatan Seksual dan Reproduksi. Semarang: Makara, Kesehatan Vol.10 No.1, Juni 2006: 29-40. 